
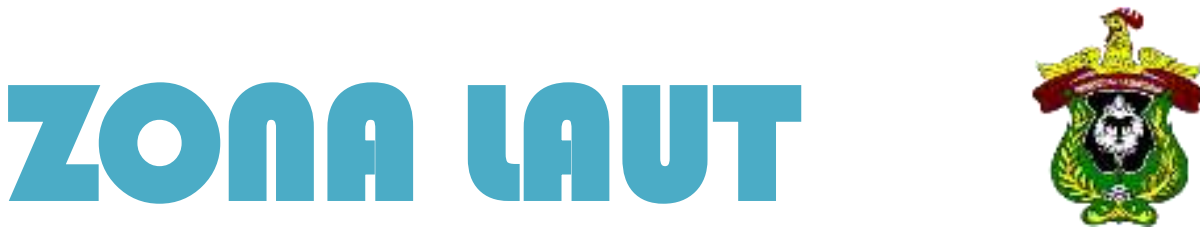

JURNAL INOVASI SAINS DAN TEKNOLOGI KELAUTAN

\title{
KANDUNGAN NITRAT DI PERAIRAN PASIR PUTIH, KECAMATAN BUNGATAN, KABUPATEN SITUBONDO
}

\author{
*Anita Diah Pahlewi ${ }^{1)}$ dan Wazirotus Sakinah ${ }^{2)}$ \\ ${ }^{1)}$ Prodi Teknik Kelautan Fakultas Pertanian Universitas Abdurachman Saleh Situbondo \\ ${ }^{2)}$ Prodi Konstruksi Perkapalan Fakultas Teknik Universitas Jember \\ * anita02@gmail.com
}

\begin{abstract}
Abstrak
Komponen fisika, kimia dan biologi yang terkandung dalam suatu perairan akan mempengaruhi kehidupan biota di dalamnya. Nitrat merupakan bentuk utama nitrogen di perairan alami dan nutrien utama bagi pertumbuhan alga. Tujuan penelitian ini adalah mengetahui kandungan nitrat yang terdapat di perairan Pasir Putih, sehingga data penelitian ini bisa dimanfaatkan untuk monitoring kualitas air di perairan Pasir Putih, Kecamatan Bungatan, Kabupaten Situbondo. Pengambilan data nitrat dalam sampel air laut dilakukan di tiga stasiun penelitian menggunakan metode analisa di laboratorium. Sampel air laut dimasukkan ke dalam botol gelap dan disimpan dalam coolbox untuk dianalisis di laboratorium, kemudian hasilnya dibandingkan dengan baku mutu air laut berdasarkan KEPMEN-LH No. 51 Tahun 2004. Rerata kadar nitrat di stasiun A yaitu 6,8 mg/L; di stasiun B yaitu 10,2 mg/L; di stasiun C yaitu 5,6 mg/L. Kandungan rerata nitrat di 3 stasiun penelitian sebesar 7,53 mg/L menunjukkan kadar nitrat yang melebihi baku mutu air laut berdasarkan KEPMEN-LH No. 51 Tahun 2004. Hal ini mengindikasikan terjadinya pencemaran antropogenik di perairan tersebut. Terdapat keramba jaring apung yang berada di dekat lokasi penelitian di perairan Pasir Putih Kabupaten Situbondo. Perlu penelitian lebih lanjut mengenai kaitan adanya keramba jaring apung dengan kualitas air di lokasi penelitian.
\end{abstract}

Kata Kunci: Nitrat, Kualitas Air, Pasir Putih Situbondo.

\section{Abstract}

The biological, chemical and physical compounds in waters will effect the life of the biota in it. Nitrate is the main form of nitrogen in natural waters and the major nutrient for alga growth. The aim of this research is determining the concentration of nitrate in Pasir Putih waters, so that the research data can be utilized as water quality monitoring in Pasir Putih waters, Bungatan district, Situbondo regency. The nitrate data in marine waters sampling was collected from three stations and through laboratory analysis methods. The marine waters samples ware putted in dark glass bottles and stored in coolbox for laboratory analysis, then the data results was compared with water quality standard based on the Decree of the State Minister of the Environment Number 51 of 2004. The average of the concentration of nitrate at station A is 6,8 $\mathrm{mg} / \mathrm{l}$; at station B is 10,2 $\mathrm{mg} / \mathrm{l}$; at station $C$ is 5,6 $\mathrm{mg} / \mathrm{l}$. The average of nitrate concentration at sampling stations is 7,53 mg/L shows that nitrate concentration level is exceed the water quality standard based on the Decree of the State Minister of the Environment Number 51 of 2004. This leads to an indication of anthropogenic pollution in the waters due to the existence of floating net cages near the research location at Pasir Putih waters Situbondo regency. It needs further researchs about the presence of floating net cages to the surrounding water quality.

Keywords: Nitrate, Water Quality, Situbondo's Pasir Putih.

\section{PENDAHULAN}

Kehidupan berlangsung tidak hanya di daratan, tetapi juga di perairan. Makhluk hidup yang tinggal di perairan sangat berhubungan erat dengan air sebagai lingkungan tempat hidupnya. Komponen fisika, kimia, dan biologi yang terkandung dalam suatu perairan akan mempengaruhi kehidupan biota di dalamnya. Biota yang hidup di 
suatu lingkungan perairan, memiliki batas-batas toleransi terhadap komponen-komponen yang terkandung dalam air untuk dapat tumbuh dan berkembang dengan baik. Apabila komponen-komponen yang terkandung dalam air tersedia dalam jumlah terlalu sedikit atau terlalu banyak, maka hal tersebut akan menjadi faktor pembatas kehidupan biota untuk tumbuh dan berkembang [1]. Nitrat $\left(\mathrm{NO}_{3}\right)$ merupakan salah satu bentuk nitrogen anorganik yang terdapat di perairan dan termasuk makro nutrien yang dibutuhkan fitoplankton dalam jumlah banyak [2]. Nitrat menjadi nutrien utama untuk pertumbuhan tanaman dan alga. Nitrat yang merupakan sumber nitrogen bagi tumbuhan dikonversi menjadi protein melalui proses [3]. Kekurangan unsur $\mathrm{N}$ dan $\mathrm{P}$ bisa menyebabkan pertumbuhan fitoplankton akan terganggu atau populasinya akan menurun [2]. Sebaliknya, kadar nitrat-nitrogen yang berlebihan bisa menyebabkan pengayaan perairan dan mempercepat pertumbuhan alga dan tumbuhan air sehingga terjadi blooming.

Pasir Putih merupakan salah satu desa di Kecamatan Bungatan dengan panjang garis pantai sekitar $5 \mathrm{Km}^{2}$ dan terdapat 49 unit perikanan budidaya [4]. Perairan Pasir Putih Situbondo merupakan salah satu objek wisata bahari di Kabupaten Situbondo. Objek wisata yang ditawarkan berupa pemandangan laut dengan pasir pantainya yang berwarna putih, menyelam, snorkeling, naik perahu, dan lain sebagainya. Aktivitas wisata dan budidaya perikanan di desa Pasir Putih menjadi penggerak kegiatan perekonomian masyarakat di wilayah tersebut. Muthahharah dan Adiwibowo [5] menyimpulkan dalam penelitiannya bahwa masyarakat mendapatkan manfaat ekonomi dari adanya objek wisata pantai pasir putih. Perairan Pasir Putih yang memberikan kontribusi positif bagi kehidupan masyarakat sekitar harus terjaga kualitasnya agar pemanfaatannya dapat berlangsung secara berkelanjutan. Oleh karena itu, monitoring kualitas perairan melalui penelitian kadar nitrat di perairan Pasir Putih perlu dilakukan sebagai fungsi pengawasan terhadap keseimbangan ekosistem perairannya.

Penelitian mengenai kualitas air di Keramba Jaring Apung Pasir Putih Situbondo dilakukan oleh P Anrosana [6] menunjukkan bahwa kualitas air di kawasan keramba jaring apung secara umum masih sesuai baku mutu air laut, tetapi data hasil penelitian yaitu salinitas dan nitrat melebihi baku mutu yang ditetapkan Kepmen LH No. 51 Tahun 2004 [7]. Data parameter lingkungan dalam penelitian Subagio dan Aunurohim [8] menunjukkan parameter fisik perairan yang meliputi kecerahan dan salinitas tidak ada yang melebihi batas rentang hidup untuk spons laut. Penelitian mengenai kadar nitrat yang terkandung di perairan Pasir Putih belum dilakukan. Penelitian ini bertujuan untuk mengetahui kandungan nitrat yang terdapat di perairan Pasir Putih, Kecamatan Bungatan, Kabupaten Situbondo. Data penelitian kadar nitrat ini bisa dimanfaatkan sebagai dasar penelitian selanjutnya untuk kegiatan monitoring dan penentuan status kualitas perairan Pasir Putih Situbondo.

\section{METODE}

Lokasi penelitian di perairan Pasir Putih Kecamatan Bungatan Kabupaten Situbondo, Jawa Timur dan Laboratorium Penguji Balai Perikanan Budidaya Air Payau (BPBAP) Situbondo. Penelitian dilaksanakan pada bulan Oktober 2018.

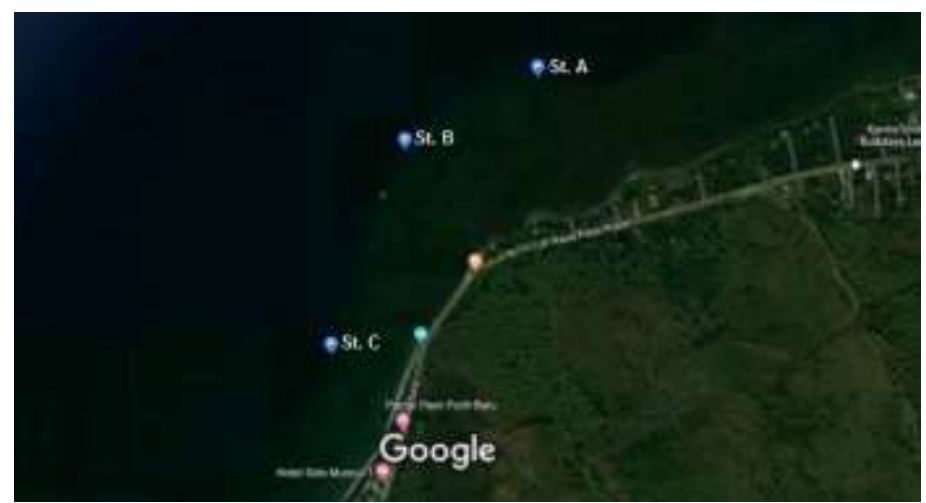

Gambar 1. Lokasi Penelitian di Perairan Pasir Putih Situbondo [8]

Pengambilan sample air menggunakan water sampling grab dilakukan pada 3 stasiun penelitian dimana pada setiap stasiun penelitian diambil sampel air dari 2 kedalaman yaitu $0,5 \mathrm{~m}$ dari permukaan perairan dan $0,5 \mathrm{~m}$ dari dasar perairan. Pengambilan sampel air laut untuk dianalisa di laboratorium dilakukan dengan memasukkan sampel air laut ke dalam botol gelap, kemudian disimpan dalam cool box dan dibawa ke 
Laboratorium Penguji dalam waktu 24 jam. Jenis parameter kualitas air yang diuji dalam penelitian ini dan spesifikasi metode dan/ alat yang digunakan disajikan pada Tabel 1.

Tabel 1. Parameter dan Spesifikasi Metode dan/ Alat Penelitian

\begin{tabular}{ll}
\hline Parameter & Spesifikasi Metode dan/ Alat \\
\hline Koordinat lokasi penelitian & GPS \\
Kedalaman perairan & Batu duga \\
Uji Nitrat $\left(\mathrm{NO}_{3}\right)$ & Kolorimetrik \\
Wadah air sampel & Botol sampel \\
Tempat botol sampel & Cool box \\
\hline
\end{tabular}

Analisis data parameter kualitas air yang didapatkan dari hasil analisa Laboratorium dilakukan secara deskriptif, yaitu dengan membandingkan hasil yang diperoleh dengan baku mutu kualitas air berdasarkan Keputusan Menteri Lingkungan Hidup Nomor 51 Tahun 2004 tentang Baku Mutu Air Laut [7].

\section{HASIL DAN PEMBAHASAN}

Lokasi pengambilan sampel air di perairan Pasir Putih ada di 3 stasiun penelitian, yaitu Stasiun A/ Karang

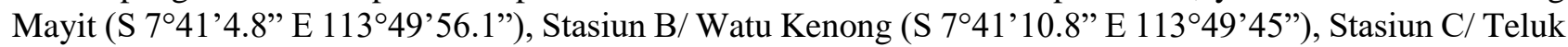
Pelita (S 7०41'27.7' E 11349'38.8”). Penelitian dilaksanakan bulan Oktober 2018 yang merupakan musim kemarau. Pada saat pengambilan sampel air, perairan dalam keadaan surut. Kedalaman perairan pada masingmasing stasiun saat pengambilan sampel diberikan pada Tabel 2.

Tabel 2. Kedalaman Perairan saat Surut

\begin{tabular}{|c|c|c|}
\hline Lokasi & Koordinat & $\begin{array}{l}\text { Kedalaman } \\
\text { (meter) }\end{array}$ \\
\hline Stasiun A/ Karang Mayit & $\mathrm{S} 7^{\circ} 41^{\prime} 4.8^{\prime \prime} \mathrm{E} 113^{\circ} 49^{\prime} 56.1^{\prime \prime}$ & 4 \\
\hline Stasiun B/ Watu Kenong & $\mathrm{S} 7^{\circ} 41^{\prime} 10.8^{\prime \prime}$ E $113^{\circ} 49^{\prime} 45^{\prime \prime}$ & 5,5 \\
\hline Stasiun C/ Teluk Pelita & S 7०41'27.7" E 11349’38.8" & 5 \\
\hline
\end{tabular}

Sampel air yang telah dikumpulkan di dalam 6 buah botol gelap kemudian dibawa untuk dianalisa di Laboratorium Penguji BPBAP Situbondo. Hasil pengujian sampel air disajikan pada Tabel 3.

Tabel 3. Hasil Pengujian Nitrat $\left(\mathrm{NO}_{3}\right)$ di Laboratorium

\begin{tabular}{lcllllll}
\hline Parameter & Satuan & Hasil \\
\hline & & A1 & A2 & B1 & B2 & C1 & C2 \\
Nitrat $\left(\mathrm{NO}_{3}\right)$ & $\mathrm{mg} / \mathrm{L}$ & 6,0 & 7,6 & 9,3 & 11,1 & 5,8 & 5,4 \\
\hline
\end{tabular}

Dimana, A1 adalah sampel air stasiun Karang Mayit 0,5 m dari permukaan perairan, A2 adalah sampel air stasiun Karang Mayit 0,5 m dari dasar perairan, B1 adalah air stasiun Watu Kenong 0,5 m dari permukaan perairan, B2 adalah air stasiun Watu Kenong $0,5 \mathrm{~m}$ dari dasar perairan, $\mathrm{C} 1$ adalah air stasiun Teluk Pelita 0,5 $\mathrm{m}$ dari permukaan perairan dan $\mathrm{C} 2$ adalah air stasiun Teluk Pelita $0,5 \mathrm{~m}$ dari dasar perairan.

Nilai rerata kandungan nitrat $\left(\mathrm{NO}_{3}\right)$ di tiga stasiun pengambilan sampel disajikan pada Tabel 4.

Tabel 4. Rerata Kandungan Nitrat $\left(\mathrm{NO}_{3}\right)$ pada Stasiun Penelitian

\begin{tabular}{lll}
\hline Lokasi & Satuan & Rerata $\mathrm{NO}_{3}$ \\
\hline Stasiun Karang Mayit & $\mathrm{mg} / \mathrm{L}$ & 6,8 \\
Stasiun Watu Kenong & $\mathrm{mg} / \mathrm{L}$ & 10,2 \\
Stasiun Teluk Pelita & $\mathrm{mg} / \mathrm{L}$ & 5,6 \\
\hline
\end{tabular}

Perbandingan hasil pengujian kandungan nitrat berdasarkan analisa laboratorium dengan standar baku mutu air laut untuk wisata bahari dan biota laut berdasarkan Keputusan Menteri Negara Lingkungan Hidup No. 51 Tahun 2004 diberikan pada Tabel 5. 
Tabel 5. Perbandingan Rerata Kandungan Nitrat Hasil Pengujian dengan Standar Baku Mutu Pemerintah

\begin{tabular}{lllllll}
\hline Parameter & $\begin{array}{l}\text { Baku Mutu untuk } \\
\text { Wisata Bahari }\end{array}$ & $\begin{array}{l}\text { Baku Mutu untuk } \\
\text { Biota laut }\end{array}$ & Satuan & & \multicolumn{4}{l}{ Rerata Hasil Uji } \\
\cline { 5 - 7 } & 0,008 & 0,008 & $\mathrm{mg} / \mathrm{L}$ & 6,8 & 10,2 & 5,6 \\
\hline $\begin{array}{l}\text { Nitrat } \\
\left(\mathrm{NO}_{3}\right)\end{array}$ & 0,008 A & Stasiun B & Stasiun C \\
\hline
\end{tabular}

Tabel 3 menunjukkan bahwa hasil pengujian kandungan nitrat tertinggi pada sampel air laut di stasiun B dan terendah di stasiun C. Pada stasiun A dan B, kandungan nitrat pada sampel air laut di bagian dasar perairan lebih tinggi dibandingkan dengan kandungan nitrat di bagian permukaan. Tetapi, hal yang sebaliknya terjadi di stasiun C. Hal tersebut menggambarkan distribusi nitrat yang tidak merata di badan perairan. Hal ini bisa dipengaruhi faktor oseanografi perairan, faktor musim, topografi, lokasi stasiun sampling, ataupun sumber masukan dari sungai/buangan limbah daratan. Perbandingan kandungan nitrat pada sampel air laut dibagian permukaan dengan dibagian dasar dapat diilustrasikan dalam Gambar 2.

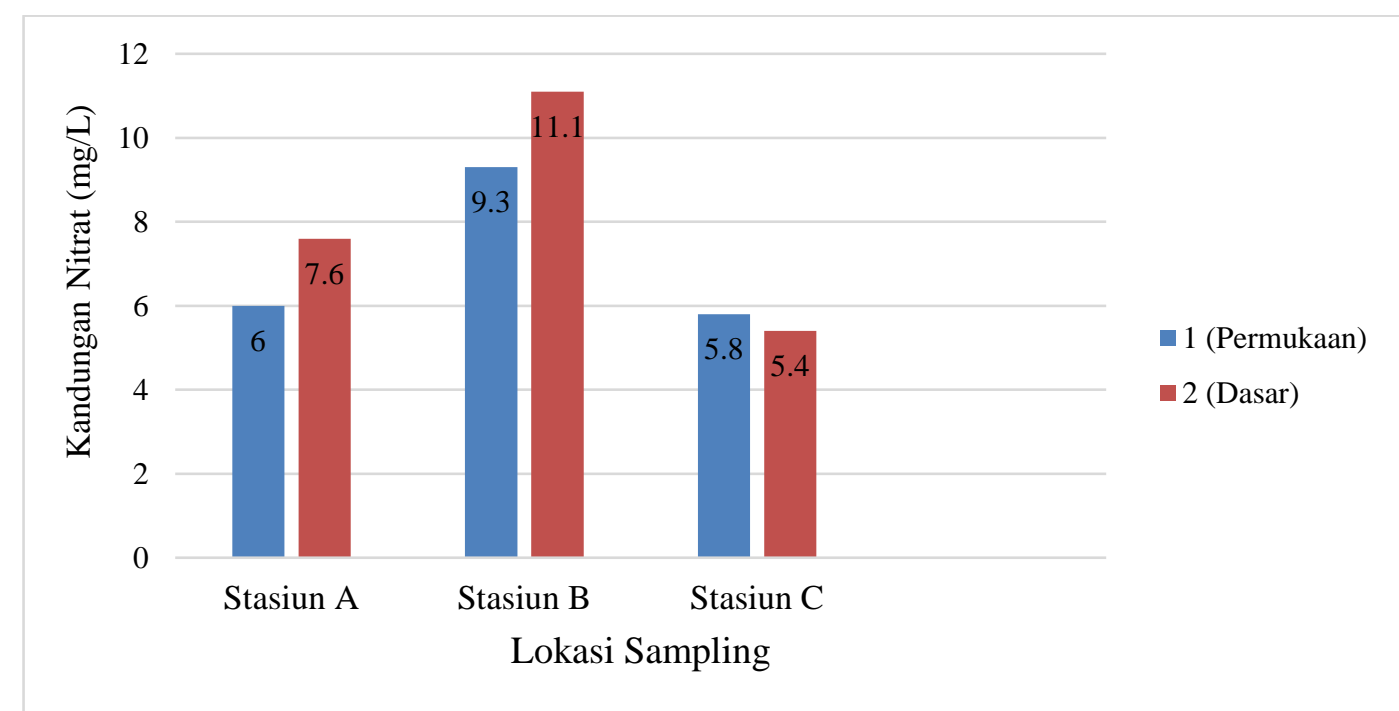

Gambar 2. Perbandingan Kandungan Nitrat di Bagian Permukaan dengan di Bagian Dasar Perairan

Tabel 4 menunjukkan nilai rata-rata kandungan nitrat di tiga stasiun sampling. Nilai rerata nitrat di Stasiun A/ stasiun Karang Mayit yaitu 6,8 mg/L, rerata kandungan nitrat di stasiun B/ stasiun Watu Kenong sebesar 10,2 $\mathrm{mg} / \mathrm{L}$, dan rerata kandungan nitrat di stasiun C/ stasiun Teluk Pelita adalah 5,6 mg/L. Data tersebut ditampilkan pada Gambar 3.

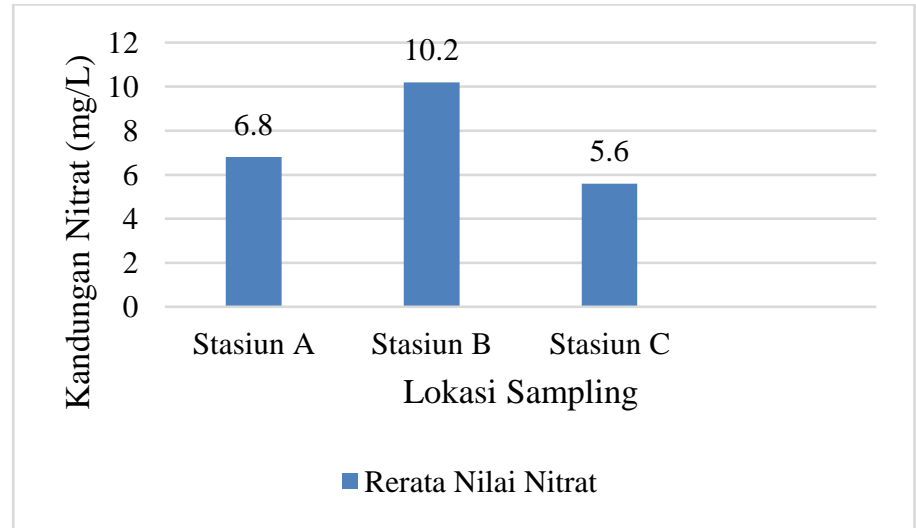

Gambar 3. Rerata Kandungan Nitrat

copyright is published under Lisensi Creative Commons Atribusi 4.0 Internasional. 
Melalui ilustrasi pada Gambar 3 diketahui kandungan tertinggi nitrat berada pada stasiun B/ Watu Kenong yaitu sebesar 10,2 mg/L dan terendah di stasiun C/ Teluk Pelita dengan nilai 5,6 mg/L. Rerata kadar nitrat di tiga lokasi sampling adalah sebesar 7,53 mg/L. Tingginya kandungan nitrat di stasiun Watu Kenong bisa disebabkan karena pengaruh lokasi Watu Kenong yang lebih dekat dengan lokasi Karamba Jaring Apung di Pasir Putih. Penumpukan sisa pakan dan feses ikan KJA meningkatkan kandungan nitrat di perairan dan terbawa oleh proses oseanografi perairan sehingga mempengaruhi kualitas air disekitarnya [10].

Kandungan nitrat di semua stasiun pengambilan sampel melebihi standar baku mutu menurut Keputusan Menteri Negara Lingkungan Hidup No. 51 Tahun 2004, dimana nilai ambang batas kandungan nitrat untuk wisata bahari dan biota laut adalah 0,008 $\mathrm{mg} / \mathrm{L}$. Menurut Effendi [3] apabila kandungan nitrat lebih dari 5 $\mathrm{mg} / \mathrm{L}$ mengindikasikan terjadinya pencemaran antropogenik yang disebabkan oleh aktivitas manusia dan tinja hewan. Bahkan kadar nitrat lebih dari $0,2 \mathrm{mg} / \mathrm{L}$ bisa mengakibatkan eutrofikasi perairan yang merangsang pertumbuhan alga dan tumbuhan air secara cepat. Nitrat dijadikan acuan sebagai klasifikasi perairan berdasarkan indikator tingkat kesuburannya. Perairan oligotrofik memiliki kadar nitrat antara $0-1 \mathrm{mg} / \mathrm{L}$, perairan mesotrofik dengan rentang kadar nitrat $1-5 \mathrm{mg} / \mathrm{L}$, dan perairan eutrofik dengan kadar nitrat 5-50 mg/L [11]. Berdasarkan data kandungan nitrat, perairan Pasir Putih Situbondo termasuk dalam kelompok perairan eutrofik.

\section{KESIMPULAN}

Kandungan nitrat diperairan Pasir Putih Situbondo melebihi nilai ambang batas baku mutu yang ditetapkan oleh Pemerintah. Nilai rerata kandungan nitrat di 3 lokasi sampling sebesar 7,53 mg/L mengindikasikan terjadinya pencemaran antropogenik yang disebabkan oleh aktivitas manusia dan tinja hewan. Hal ini bisa dikarenakan lokasi sampling yang berdekatan dengan KJA di perairan Pasir Putih Situbondo.

\section{DAFTAR PUSTAKA}

[1] E.P. Odum, Dasar-Dasar Ekologi, Edisi ketiga, Yogyakarta: Gadjah Mada University Press, 1996.

[2] A. Mustofa, "Kandungan Nitrat dan Pospat sebagai Faktor Tingkat Kesuburan Perairan Pantai", Jurnal DISPROTEK, vol. 6, no. 1, hal. 13-19, 2015.

[3] H. Effendi, Telaah Kualitas Air, Yogyakarta: PT Kanisius, 2003.

[4] Sukandar, C.J. Harsindhi, M. Handayani, C.S.U. Dewi, A. W. Maulana, Supriyadi, A. Bahroni, Profil Desa Pesisir Provinsi Jawa Timur, vol. 1 (Utara Jawa Timur), Surabaya: Bidang Kelautan, Pesisir, dan Pengawasan Dinas Perikanan dan Kelautan Provinsi Jawa Timur, 2016.

[5] A. Muthahharah dan S. Adiwibowo, "Dampak Obyek Wisata Pantai Pasir Putih Situbondo terhadap Peluang Bekerja dan Berusaha", JSKPM, vol. 1, no. 2, pp 157-166, 2017. [Online]. DOI: 10.29244/jskpm.1.2.157-166 [Diakses 27 Agustus 2018.

[6] I. A. Anrosana P dan A. A. Gemaputri, "Kajian Daya Dukung (Carrying capacity) Lingkungan Perairan Pantai Pasir Putih Situbondo bagi Pengembangan Usaha Keramba Jaring Apung”, Jurnal Ilmiah INOVASI, vol. 17, no. 2, pp. 73-79, 2017.

[7] Keputusan Menteri Lingkungan Hidup Nomor 51 Tahun 2004 tentang Baku Mutu Air Laut

[8] B. I. Subagio dan Aunurohim, "Struktur Komunitas Spons Laut (Porifera) di Pantai Pasir Putih, Situbondo", Jurnal Sains dan Seni POMITS, vol. 2, no. 2, pp. 159-165, 2013.

[9] Googlemaps, 2018.

[10] S. I. Patty, "Karakteristik Fosfat, Nitrat dan Oksigen Terlarut di Perairan Selat Lembeh, Sulawesi Utara", Jurnal Pesisir dan Laut Tropis, vol. 2, no. 1, pp. 1-7, 2015.

[11] M. Amien H, "Studi Kadar Nitrat dan Fosfat di Perairan Pesisir Kota Tarakan, Kalimantan Utara", Jurnal Harpodon Borneo, vol. 8, no. 1, pp. 27-34, 2015. 